\title{
$\mathrm{Fe}_{2.4} \mathrm{Sm}$ 合金薄膜の磁場誘起運動に及ぼす $\mathrm{Al}$ 基板厚さ依存性
}

\author{
中野 良1,* 松村義 人 $^{2}$ 西 義 武1,2
}

\author{
1東海大学大学院工学研究科 \\ 東海大学大学院理工学研究科 \\ J. Japan Inst. Metals, Vol. 72, No. 5 (2008), pp. 371-375 \\ (C) 2008 The Japan Institute of Metals
}

\section{Thickness Dependence of Aluminum Substrate on Magnetic Field Induced Bending Motion of Compressive Magnetostrictive $\mathrm{Fe}_{2.4} \mathrm{Sm}$ Alloy Film}

\begin{abstract}
Ryo Nakano ${ }^{1, *}$, Yoshihito Matsumura ${ }^{2}$ and Yoshitake Nishi,2
${ }^{1}$ Department of Metallurgical Engineering, Graduate School of Engineering, Tokai University, Hiratsuka 259-1292

${ }^{2}$ Department of Science and Technology, Graduate School of Science and Technology, Tokai University, Hiratsuka 259-1292

Thickness dependence of aluminum substrate on magnetic field induced bending motion of $\mathrm{Fe}_{2.4} \mathrm{Sm}$ alloy thin film prepared by direct current magnetron sputtering process was investigated. The residual gas pressure before argon sputtering and the sputtering pressure of argon gas $(5 \mathrm{~N})$ were less than $3.3 \times 10^{-4} \mathrm{~Pa}$ and $2.0 \times 10^{-1} \mathrm{~Pa}$, respectively. The thickness of the $\mathrm{Fe}_{2.4} \mathrm{Sm}$ films deposited was about $2.1 \mu \mathrm{m}$. Bending motion of $\mathrm{Fe}_{2.4} \mathrm{Sm}$ alloy film largely depended on substrate thickness. The large bending motion induced by magnetic field and its high susceptibility were found in the compressive magnetostrictive $\mathrm{Fe}_{2.4} \mathrm{Sm}$ alloy film on aluminum thin sheet.
\end{abstract}

(Received November 22, 2007; Accepted February 12, 2008)

Keywords: compressive magnetostriction, susceptibility, aluminum, iron-samarium, direct current magnetron sputtering

\section{1. 緒言}

磁性材料の磁歪効果が発見された当初は，振動子材料や音 響変換機として研究が盛んであったが，磁歪が $10 \mathrm{ppm}$ 程度 と小さく, 応用範囲が狭いため, 現在では PZT などの圧電 材料が高感度運動機能材料として実用化されている1).しか し近年，希土類一鉄系 $\mathrm{RFe}_{2}$ 構造を持つ金属間化合物系合金 結晶が $1000 \mathrm{ppm}$ 以上の超磁歪を示すことが知られてい $ろ^{2)}$. 超磁歪材料は, 高い応答性, 大きな発生応力, 低電圧 駆動が可能, さらに駆動には磁場を用いるため非接触でリ モートコントロールが可能である特徵も有し, 次世代のセン サーやアクチュエータへの応用も強く期待されている ${ }^{3-5)}$. その中でも圧縮 (負)磁歪合金である FeSm 合金薄膜は低印 加磁場での圧縮磁歪を示す6).

マグネトロンスパッタ法は薄膜作製方法として工業的に広 く用いられている方法の一つである. スパッタガス圧や基板 温度に関連した成膜条件を変えることで, 作製した薄膜の組 織が変化することが知られている7).さらに, 我々は今まで に, 超磁歪材料が薄膜運動機能素子としても優れた特性を示 すことを報告してきている8-13).

一般に, $\mathrm{Fe}-\mathrm{Sm}$ 超磁歪合金薄膜の基板はシリコンを用

\footnotetext{
* 東海大学大学院生 (Graduate Student, Tokai University)
}

い, 複合化し, 曲げ運動を評価してきた ${ }^{11-13)}$ 。しかし, 実 用化を考え, 大きな運動を得るためには, シリコンよりも, 剛性の低い基板材料を用いることも効果的な手法として考え られる.このことにより, 磁場による曲げ運動に対する変形 抵抗が小さくなり，大きな運動が得られる可能性がある．そ こで本研究では, 基板材料を現在使用しているシリコンに比 ベて剛性の低い，アルミニウムを基板として用いた．さら に，基板厚さを変化することにより， $\mathrm{Fe}_{2.4} \mathrm{Sm}$ 合金薄膜の磁 場により発現する磁化が誘起する圧縮運動歪と, その感度に 関するアルミニウム基板の厚さ依存性を検討することを目的 とした.

\section{2. 実 験 方 法}

試料作製には DC マグネトロンスパッタリング法を用い た. ターゲットには純度 $99.8 \%$, 直径 $75 \mathrm{~mm}$, 厚み $3 \mathrm{~mm}$ の $\mathrm{Fe}_{2} \mathrm{Sm}$ 合金ターゲットを使用した. $\mathrm{Fe}_{2.4} \mathrm{Sm}$ 合金薄膜の 成膜条件は到達真空度 $3.3 \times 10^{-4} \mathrm{~Pa}$ 以下，スパッタリング ガスはアルゴン (純度 $5 \mathrm{~N}$ ) でアルゴンガス圧 $0.1 \mathrm{~Pa}$ ，スパッ

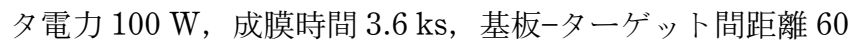
$\mathrm{mm}$, 基板温度 $423 \mathrm{~K}$ で行った.これは最も大きな磁歪が得 られる基板温度，スパッタリングガス圧の成膜条件を参考に 決定した ${ }^{8-13)}$.

基板にはシリコンと，アンカー効果を得るためにエメリー 
紙 2000 番で表面を研磨したアルミニウム板 (99.9 mass\%) を用いた，基板厚さは，シリコンが $280 \mu \mathrm{m}$ ，アルミニウム が 100, 200, $300 \mu \mathrm{m}$ とした．組成分析はエネルギー分散型 X 線分光法 (EDS: EMAX-5770, HORIBA)を用いた。構造 解析には薄膜 X 線回折装置 (XRD: $\mathrm{Cu} \mathrm{K} \alpha$ 線 ; X'PartMRD, PHILIPS) を用いた。膜厚測定は表面形状測定装置 $\left(\mathrm{DEKTAK}^{3}\right.$ ，日本真空侏）を用いた。磁歪測定は光梃子法を 用い，面内方向に $\pm 1.2 \mathrm{MA} / \mathrm{m}$ の磁場を印加した.

\section{3. 実 験 結 果}

Fig. 1 にシリコンと厚さの異なるアルミニウム基板上に蒸 着された $\mathrm{Fe}_{2.4} \mathrm{Sm}$ 合金薄膜におけるまでの印加磁場と角度 の関係を示す。な扮角度 $\alpha$ は，後述の式 $(4)$ にて与えられ るパラメータ $d$ を $\tan ^{-1} d$ にて求めた值である. アルミニウ 厶基板に成膜した $\mathrm{Fe}_{2.4} \mathrm{Sm}$ 合金薄膜は，印加磁場 $400 \mathrm{kA} / \mathrm{m}$ に扔いて基板厚さ $100 \mu \mathrm{m}$ で $3.1 \mathrm{mrad}, 200 \mu \mathrm{m}$ で $2.3 \mathrm{mrad}$, $300 \mu \mathrm{m}$ で $1.1 \mathrm{mrad}$ の角度となり，基板厚さが薄いほど角 度が大きいことを確認した. また，シリコン基板に成膜した $\mathrm{Fe}_{2.4} \mathrm{Sm}$ 合金薄膜は， $0.4 \mathrm{mrad}$ となった．この結果，アルミ ニウム $100 \mu \mathrm{m}$ の薄い基板を用いた $\mathrm{Fe}_{2.4} \mathrm{Sm}$ 合金運動機能薄 膜では磁場により誘起された運動が大きく，それに比べてア ルミニウム $200 \mu \mathrm{m}$ と $300 \mu \mathrm{m}$ ，シリコン基板 $280 \mu \mathrm{m}$ の厚 い基板を用いた運動機能薄膜では磁場により誘起された運動 が非常に小さいことが，直接的にわかる.

Fig. 2 に Al 基板厚さ $100 \mu \mathrm{m}, 200 \mu \mathrm{m}, 300 \mu \mathrm{m}, \mathrm{Si}$ 基板厚 さ $280 \mu \mathrm{m}$ に打ける $\mathrm{Fe}_{2.4} \mathrm{Sm}$ 合金薄膜の $\mathrm{X}$ 線回折図を示 す。な拉，参考のために図上方に ICDD カードの結晶ピー ク強度比を示す15). Fig. 2 より, アルミニウム以外, 特に大
きな結晶ピークは観察されず，アモルファス構造特有の $\mathrm{X}$ 線回折パターンを確認した。但し，このアモルファス相はガ ラス構造と断定するわけでなく, 結晶ピークが確認できない 程度の微結晶構造, 又は微結晶を含む可能性もある。この結 果より, 残留ガス等に由来する $\mathrm{Sm}_{2} \mathrm{O}_{3}$ 等の酸化物結晶相が 観察されず，磁歪に及ぼす酸化物の影響はほとんど無いと考 えられる11).

\section{4. 考察}

\section{1 磁場誘起運動歪のアルミニウム基板厚さ依存性}

$\mathrm{Fe}_{2.4} \mathrm{Sm}$ 合金薄膜をアルミニウム基板に蒸着した薄膜運動 素子試料全体の磁場が誘起した運動歪を次式から算出した.

$$
\varepsilon_{\mathrm{M}}=\frac{\eta}{\rho}
$$

$\eta$ は中立面からの距離, $\rho$ は中立面までの曲率半径で, 次式 より求められる值である.

$$
\begin{gathered}
\eta=\frac{t_{\mathrm{s}}+t_{\mathrm{f}}}{2} \\
\rho=R+\frac{t_{\mathrm{s}}+t_{\mathrm{f}}}{2}
\end{gathered}
$$

$t_{\mathrm{s}}, t_{\mathrm{f}}$ はそれぞれ基板および薄膜の厚さである.

また， $R$ は曲率半径であり, 次式より求められる.

$$
R=\frac{l^{2}+d^{2}}{2 d}
$$

$l$ は固定端から反射ビームスポットまでの距離， $d$ は試料の 反り角である.

さらに基板の変形抵抗を $R_{\mathrm{d}}$ とし, 次式を用いて算出した.

$$
R_{\mathrm{d}}=G_{\mathrm{S}} \times t_{\mathrm{S}}
$$

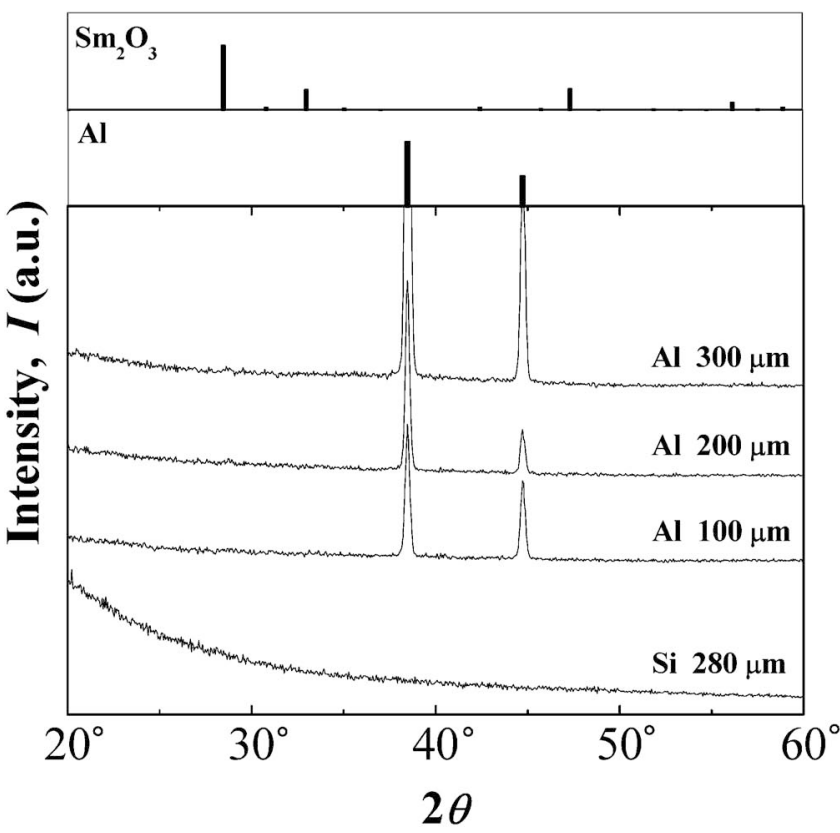

Fig. 2 X-ray diffraction patterns of $\mathrm{Fe}_{2.4} \mathrm{Sm}$ film prepared on substrate of each thickness of $280 \mu \mathrm{m}(\mathrm{Si}), 100 \mu \mathrm{m}$ (A1), 200 $\mu \mathrm{m}(\mathrm{Al})$ and $300 \mu \mathrm{m}(\mathrm{Al})$, respectively, together with standard $\mathrm{X}$-ray references of ICDD cards.

Magnetic field dependent apparent angle $(\alpha)$ of $\mathrm{Fe}_{2}$ $\mathrm{Sm}$ on Al substrate of each thickness of $100 \mu \mathrm{m}(\bigcirc), 200 \mu \mathrm{m}$ $(\triangle)$ and $300 \mu \mathrm{m}(\diamond)$, respectively, together with $\mathrm{Si}(\square)$ substrate of $280 \mu \mathrm{m}$ in thickness.

15

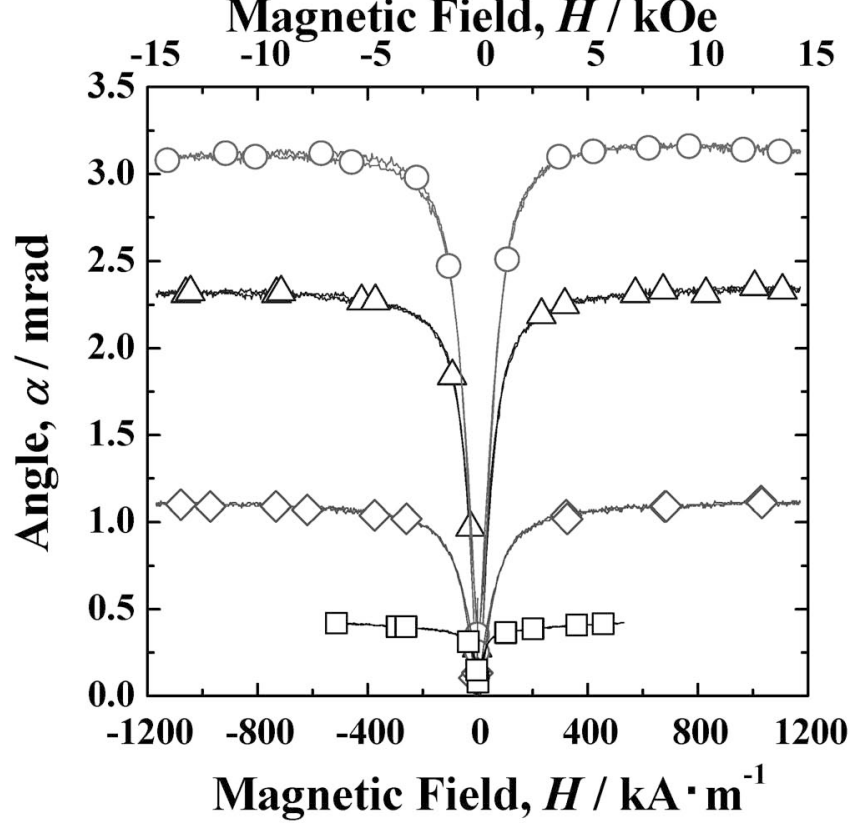


ここで $G_{\mathrm{S}}$ は基板の剛性率であり次式により求められる.

$$
G_{\mathrm{S}}=\frac{E_{\mathrm{S}}}{2\left(1+v_{\mathrm{S}}\right)}
$$

なお $E_{\mathrm{S}}$ は基板のヤング率， $v_{\mathrm{S}}$ は基板のポアソン比である.

Fig. 3 に曲率半径より算出した磁場誘起運動歪(磁場印加 により誘起された運動歪)を示す. Fig. 3 より磁場誘起運動 歪は基板厚さが薄くなるほど磁場誘起運動丕が大きくなるこ とを確認した。アルミニウム基板に成膜した $\mathrm{Fe}_{2.4} \mathrm{Sm}$ 合金 薄膜は, 印加磁場 $400 \mathrm{kA} / \mathrm{m}$ において基板厚さ $100 \mu \mathrm{m}$ で $53 \mathrm{ppm}, 200 \mu \mathrm{m}$ で $25 \mathrm{ppm}, 300 \mu \mathrm{m}$ で $16 \mathrm{ppm}$, シリコン $280 \mu \mathrm{m}$ の基板に成膜した $\mathrm{Fe}_{2.4} \mathrm{Sm}$ 合金薄膜は, $6 \mathrm{ppm}$ の磁 場誘起運動丕を示した. 基板の厚さを薄くすると, 曲げ変形 抵抗力が小さくなり, 予想どおり, 運動機能薄膜素子の磁場 誘起運動歪が増大した.

\section{2 磁歪のアルミニウム基板厚さ依存性}

$\mathrm{Fe}_{2.4} \mathrm{Sm}$ 合金薄膜の磁歪 $(\lambda)$ は光梃子法に適用される次式 を用いて算出される場合が多い14).

$$
\lambda_{/ /}=\frac{d \cdot t_{\mathrm{S}}^{2} \cdot E_{\mathrm{S}}\left(1+v_{\mathrm{f}}\right)}{3 t_{\mathrm{f}} \cdot l^{2} \cdot E_{\mathrm{f}}\left(1-v_{\mathrm{S}}\right)}
$$

前式中の $d$ は次式で求められる值である.

$$
d=\frac{l D}{2 L}
$$

これらの式で, lは固定端から反射ビームスポットまでの距 離 $(1 \mathrm{~mm}), D$ は反射ビームスポットの移動距離(最大 9.2 $\mathrm{mm})$, そして $L$ は試料から測定器までの距離 $(1.45 \mathrm{~m})$ であ る. 式 $(7)$ の $t_{\mathrm{s}}$ と $t_{\mathrm{f}}$ はアルミニウム基板厚さ $(100,200,300$ $\mu \mathrm{m})$ と $\mathrm{Fe}_{2.4} \mathrm{Sm}$ 合金薄膜の厚さ $(2.1 \mu \mathrm{m}), E_{\mathrm{s}}$ と $E_{\mathrm{f}}$ はアルミ ニウム基板のヤング率 $(69 \mathrm{GPa})$ と $\mathrm{FeSm}$ 薄膜のヤング率 (40 $\mathrm{GPa}), v_{\mathrm{s}}$ と $v_{\mathrm{f}}$ は基板のポアソン比(0.33)と $\mathrm{FeSm}$ 薄膜のポ
アソン比 (0.40)である16,17)。 また，シリコン基板の厚さは $280 \pm 20 \mu \mathrm{m}$ ，ヤング率は $130 \mathrm{GPa}$ ，ポアソン比は 0.28 であ る18). なお $\mathrm{Fe}_{2.4} \mathrm{Sm}$ 合金薄膜には, バルクのヤング率とポ アソン比を用いているが，バルクと薄膜という差以外はほと んぞ同じと仮定して考察している.

Fig. 4 に，磁歪の計算結果を示す. 印加磁場 $400 \mathrm{kA} / \mathrm{m}$ に おいてアルミニウム基板厚さ $100 \mu \mathrm{m}$ で $2900 \mathrm{ppm}, 200 \mu \mathrm{m}$ で $2800 \mathrm{ppm}, 300 \mu \mathrm{m}$ で $2700 \mathrm{ppm}$ の磁歪を確認した．厚さ $280 \mu \mathrm{m}$ のシリコン基板上に成膜した $\mathrm{Fe}_{2.4} \mathrm{Sm}$ 合金薄膜の磁 歪が，印加磁場 $400 \mathrm{kA} / \mathrm{m}$ において $1350 \mathrm{ppm}$ であるのに比 ベ，アルミニウム基板上に成膜した $\mathrm{Fe}_{2.4} \mathrm{Sm}$ 合金薄膜の磁 歪は大きく発現したことがわかる。これは，シリコン基板は ヤング率が高いため磁歪が発現しにくいのに対し, アルミニ ウム基板はヤング率が低いため，より大きな磁歪が発現でき ると説明した. さらにアルミニウム基板の表面粗さによりア ンカー効果が得られたため, $\mathrm{Fe}_{2.4} \mathrm{Sm}$ 合金薄膜の磁歪の力 が，より基板に伝わった可能性も否定できない，なお，シリ コン基板の表面粗さは, 最低谷底から最大山頂までの高さ (最大高さ) が $0.024 \mu \mathrm{m}$ ，アルミニウム基板の表面粗さは $100 \mu \mathrm{m}$ で $1.0 \mu \mathrm{m}, 200 \mu \mathrm{m}$ で $0.8 \mu \mathrm{m}, 300 \mu \mathrm{m}$ で $1.0 \mu \mathrm{m}$ で あった. さらに, 負磁歪材料として $2100 \mathrm{ppm}$ の大きな磁歪 を示す $\mathrm{Fe}_{2} \mathrm{Sm}$ 単結晶よりも大きな磁歪を示すことを確認し た ${ }^{19)}$.

基板厚さ変化により, 磁丕の值は大きく変わらない結果が 得られている.さらに, ぞの基板厚さの試料においても, 印 加磁場 $400 \mathrm{kA} / \mathrm{m}$ で磁歪はほぼ飽和していた。これは, 磁 歪薄膜を拘束しているのは柔らかいアルミニウム基板の表面 のみであり, アルミニウム基板の柔らかさにより磁丕薄膜が 自由に磁歪運動することを示している.これに対し, 磁場誘 起運動歪は試料全体の歪を曲率半径から算出しているため,

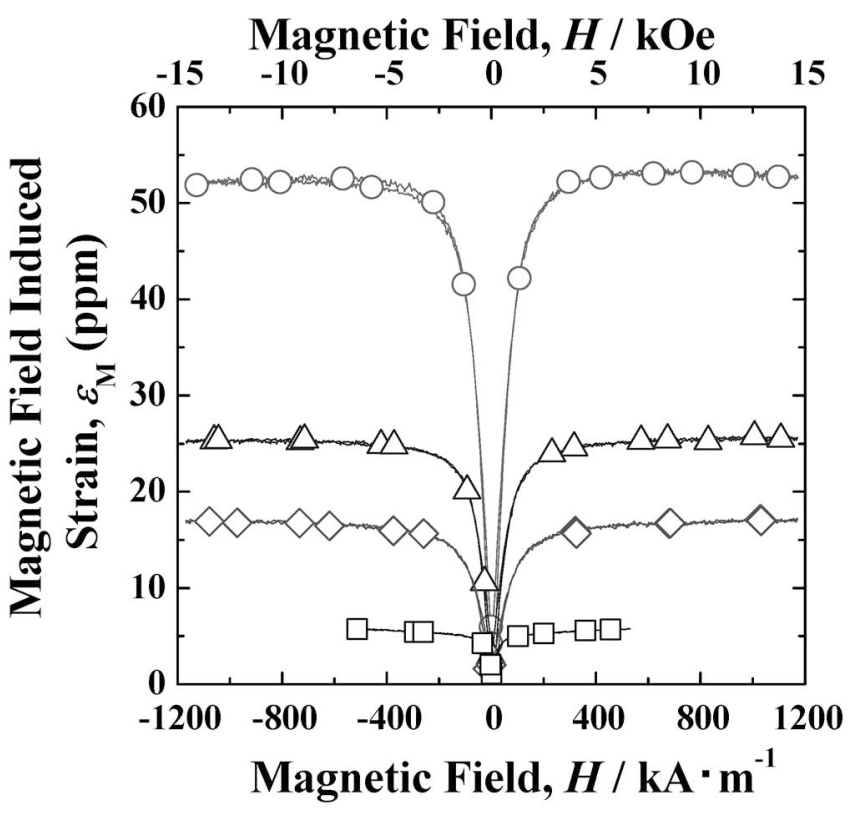

Fig. 3 Magnetic field dependent magnetic field induced strain $\left(\varepsilon_{\mathrm{M}}\right)$ of $\mathrm{Fe}_{2.4} \mathrm{Sm}$ on $\mathrm{Al}$ substrate of each thickness of $100 \mu \mathrm{m}$ $(\bigcirc), 200 \mu \mathrm{m}(\triangle)$ and $300 \mu \mathrm{m}(\diamond)$, respectively, together with Si $(\square)$ substrate of $280 \mu \mathrm{m}$ in thickness.

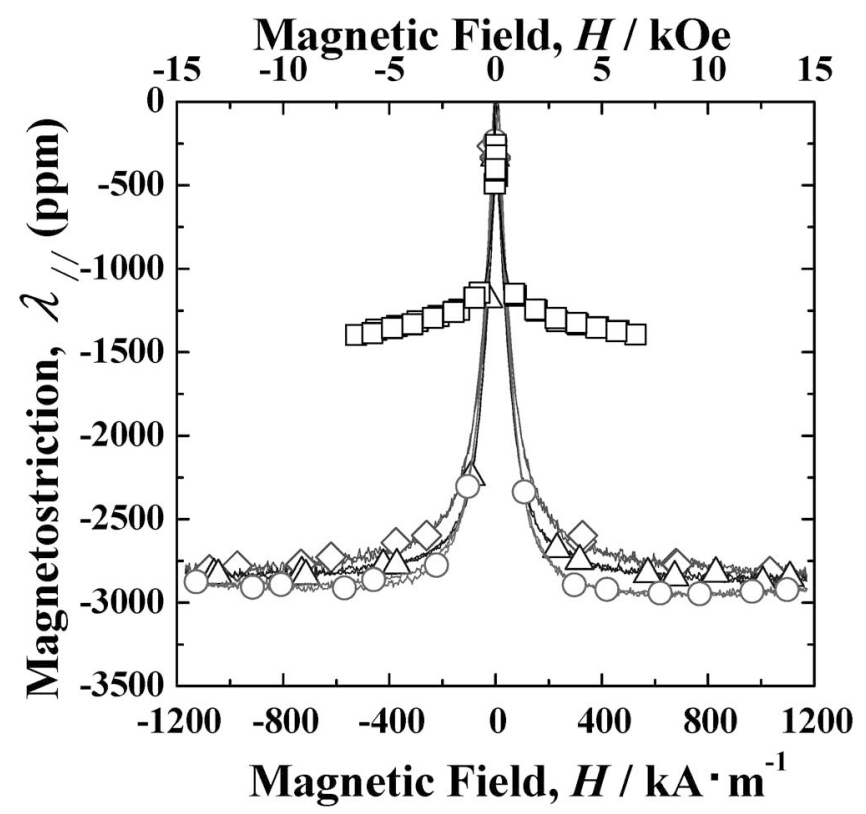

Fig. 4 Magnetic field dependent magnetostriction $(\lambda)$ of $\mathrm{Fe}_{2.4}$ $\mathrm{Sm}$ on Al substrate of each thickness of $100 \mu \mathrm{m}(\bigcirc), 200 \mu \mathrm{m}$ $(\triangle)$ and $300 \mu \mathrm{m}(\diamond)$, respectively, together with $\mathrm{Si}(\square)$ substrate of $280 \mu \mathrm{m}$ in thickness. 
現実の素子全体の運動を評価し, 基板厚さによる依存性が見 られたと考えている.すなわち, 運動機能薄膜素子として実 際に用いる場合, 実際の運動変位は Fig. 1 の運動角度の変 化やFig. 3 の磁場誘起運動歪が近く, 実際の機器では重要 である。

\section{3 磁歪感受率と磁場誘起運動歪感受率のアルミニウム基 板厚さ依存性}

Fig. 4 の磁歪曲線の傾きから運動機能素子の感度の指標に なる磁歪感受率を計算した。.Fig. 5 に基板厚さの異なる $\mathrm{Fe}_{2.4} \mathrm{Sm}$ 合金薄膜の磁丕感受率の印加磁場 $300 \mathrm{kA} / \mathrm{m}$ までに おける磁場依存性を示す。アルミニウム基板に成膜した $\mathrm{Fe}_{2.4} \mathrm{Sm}$ 合金薄膜は, 印加磁場 $20 \mathrm{kA} / \mathrm{m}$ において磁歪感受 率は最大となり, $100 \mu \mathrm{m}$ で $25 \mathrm{ppm} / \mathrm{kA} \cdot \mathrm{m}^{-1}, 200 \mu \mathrm{m}$ で 27 $\mathrm{ppm} / \mathrm{kA} \cdot \mathrm{m}^{-1}, 300 \mu \mathrm{m}$ で $23 \mathrm{ppm} / \mathrm{kA} \cdot \mathrm{m}^{-1}, 280 \mu \mathrm{m}$ のシリ コン基板に成膜した $\mathrm{Fe}_{2.4} \mathrm{Sm}$ 合金薄膜は, $20 \mathrm{ppm} / \mathrm{kA} \cdot \mathrm{m}^{-1}$ の磁歪感受率を確認した。 また $160 \mathrm{kA} / \mathrm{m}$ の印加磁場で零 に近付くことを確認した.

一方, Fig. 3 の磁場誘起運動歪曲線の傾きから運動機能素 子の感度の指標になる磁場誘起運動歪の感受率を計算した.

Fig. 6 に基板厚さの異なる $\mathrm{Fe}_{2.4} \mathrm{Sm}$ 合金薄膜の磁場誘起運動 歪に関する感受率の印加磁場 $300 \mathrm{kA} / \mathrm{m}$ までにおける磁場 依存性を示す. 印加磁場 $20 \sim 60 \mathrm{kA} / \mathrm{m}$ において磁場誘起運 動歪の感受率が最大となる.アルミニウム基板に成膜した $\mathrm{Fe}_{2.4} \mathrm{Sm}$ 合金薄膜は, 印加磁場 $20 \mathrm{kA} / \mathrm{m}$ において基板厚さ $100 \mu \mathrm{m}$ で $0.39 \mathrm{ppm} / \mathrm{kA} \cdot \mathrm{m}^{-1}, 200 \mu \mathrm{m}$ で $0.22 \mathrm{ppm} / \mathrm{kA}$. $\mathrm{m}^{-1}, 300 \mu \mathrm{m}$, で $0.12 \mathrm{ppm} / \mathrm{kA} \cdot \mathrm{m}^{-1}, 280 \mu \mathrm{m}$ シリコンの基 板に成膜した $\mathrm{Fe}_{2.4} \mathrm{Sm}$ 合金薄膜は, $0.08 \mathrm{ppm} / \mathrm{kA} \cdot \mathrm{m}^{-1}$ の磁 場誘起運動歪感受率を示した。 また, 磁歪感受率と同様に,
$160 \mathrm{kA} / \mathrm{m}$ の印加磁場で零に近づくことを確認した．さらに， Fig. 6 の磁場誘起運動歪の感受率では基板厚さが薄くなるほ ど值が大きくなることを確認した．これは，アルミニウムの 板厚の低下に伴い, 変形抵抗が低下したことによる.

磁歪では膜のみの歪を求めているので, 基板厚さの影響が ほとんど見られなかったと考察した.

一方, 磁場誘起運動歪は複合薄膜の運動歪を求めているの で，基板厚さの減少に伴い，基板の曲げ変形抵抗が減少し， 磁場誘起運動歪が増加したと考察した。

磁歪と磁場誘起運動歪感受率は印加磁場 20〜60 kA/m の 時に最大となり $160 \mathrm{kA} / \mathrm{m}$ の印加磁場で零に近付くことを 確認した. 磁歪感受率では基板厚さによる大きな差は見られ なかったが, 磁場誘起運動歪感受率については基板厚さが薄 いほど大きな值を示すことを確認した。

以上の結果よりアルミニウムを基板に用いることは, $\mathrm{Fe}_{2.4} \mathrm{Sm}$ 合金薄膜の特徵である高感受率, 高磁歪を維持した まま，大きな磁場誘起運動歪を得ることを確認した。また， 新たに磁場誘起運動丕とその感受率を用いて評価したことに より, 磁歪材料の評価だけでなく, デバイスに用いる際の設 計指標を提案した.

\section{5. 結 論}

$\mathrm{DC}$ マグネトロンスパッタリング装置を用い, $\mathrm{Fe}_{2.4} \mathrm{Sm}$ 負 磁歪合金薄膜を厚さの異なるアルミニウム基板上に蒸着し, 運動機能薄膜素子を作製した. 磁場印加により誘起された膜 のみの運動歪である磁歪と, 現実の機構設計因子に必要な試 料全体の運動である磁場誘起運動丕を算出し, さらにそれぞ れの感受率を計算し, 検討した. $1 \mathrm{MA} / \mathrm{m}$ の印加磁場にお

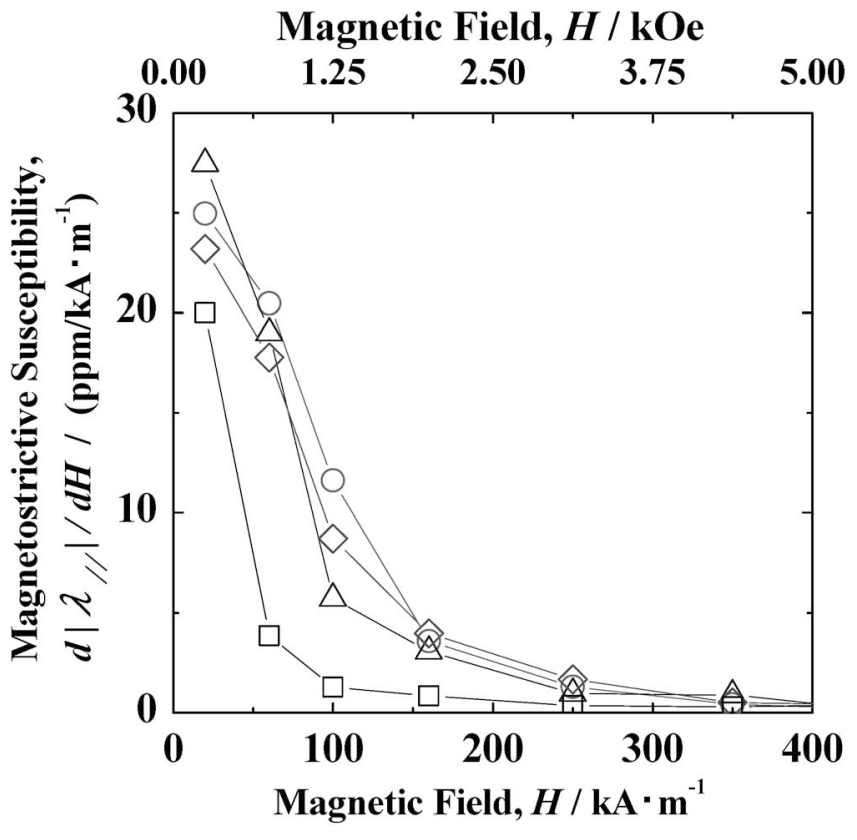

Fig. 5 Applied magnetic field dependent magnetostrictive susceptibility $\left(d\left|\lambda_{/ /}\right| / d H\right)$ of $\mathrm{Fe}_{2.4} \mathrm{Sm}$ on Al substrate of each thickness of $100 \mu \mathrm{m}(\bigcirc), 200 \mu \mathrm{m}(\triangle)$ and $300 \mu \mathrm{m}(\diamond)$, respectively, together with $\mathrm{Si}(\square)$ substrate of $280 \mu \mathrm{m}$ in thickness.

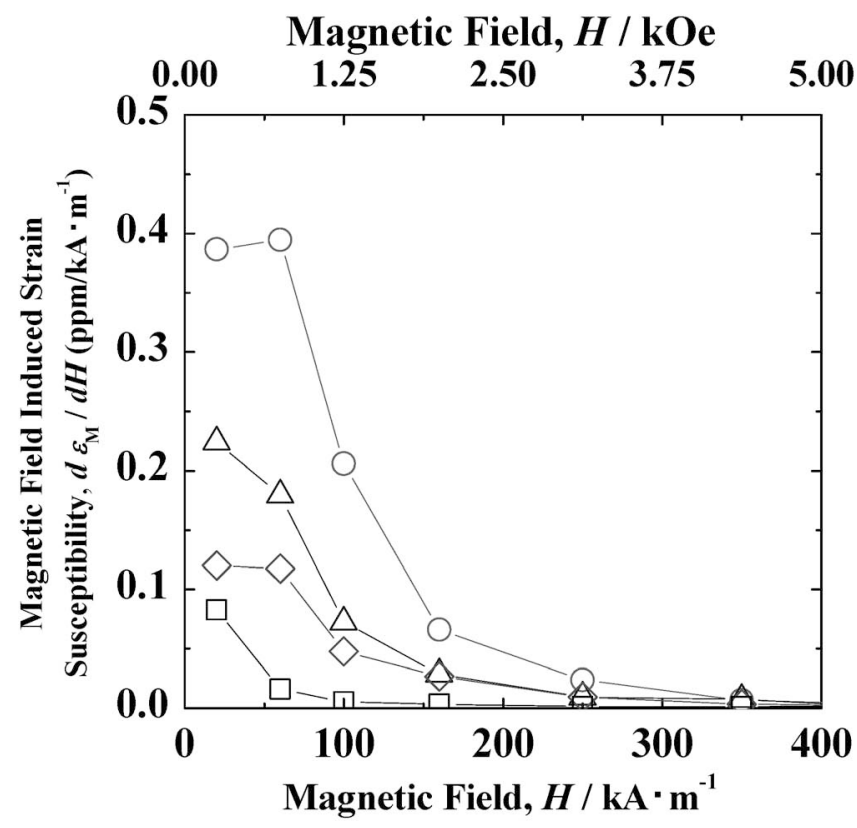

Fig. 6 Applied magnetic field dependent magnec field induced strain $\left(d \varepsilon_{\mathrm{M}} / d H\right)$ susceptibility of $\mathrm{Fe}_{2.4} \mathrm{Sm}$ on $\mathrm{Al}$ substrate of each thickness of $100 \mu \mathrm{m}(\bigcirc), 200 \mu \mathrm{m}(\triangle)$ and $300 \mu \mathrm{m}$ $(\diamond)$, respectively, together with $\mathrm{Si}(\square)$ substrate of $280 \mu \mathrm{m}$ in thickness. 
いて，基板厚さにより $\mathrm{Fe}_{2.4} \mathrm{Sm}$ 合金薄膜の磁歪 $\lambda$ に大きな 差は見られないことを確認した。 しかし, 印加磁場 $1 \mathrm{MA} /$ $\mathrm{m}$ に打ける $\mathrm{Fe}_{2.4} \mathrm{Sm}$ 合金薄膜の磁場誘起運動丕について は, 基板厚さが薄くなるほど磁場誘起運動丕が大きくなるこ とを確認した.

印加磁場 $1 \mathrm{MA} / \mathrm{m}$ において磁歪はアルミニウムの基板厚 さ $100 \mu \mathrm{m}$ で $2935 \mathrm{ppm}, 200 \mu \mathrm{m}$ で $2858 \mathrm{ppm}, 300 \mu \mathrm{m}$ で $2818 \mathrm{ppm}$, 磁場誘起運動歪は基板厚さ $100 \mu \mathrm{m}$ で $53 \mathrm{ppm}$, $200 \mu \mathrm{m}$ で $26 \mathrm{ppm}, 300 \mu \mathrm{m}$ で $17 \mathrm{ppm}$ を示すことを確認し た。

これはアルミニウム基板を研磨したことにより得られた表 面粗さによってアンカー効果が得られたため, $\mathrm{Fe}_{2.4} \mathrm{Sm}$ 合金 薄膜の磁歪の力が, シリコン基板に比べて, より伝わった可 能性があることだけでなく, アルミニウムの低い弾性率が変 形抵抗を低下させ運動歪を増大させたと説明した。

また, 磁歪では膜のみの歪を求めているので, 基板厚さの 影響がほとんど見られなかったと考察した。

一方, 磁場誘起運動歪は複合薄膜の運動歪を求めているの で, 基板厚さの減少に伴い, 基板の曲げ变形抵抗が減少し, 磁場誘起運動歪が増加したと考察した。

磁歪と磁場誘起運動歪の感受率は印加磁場 $20 \sim 60 \mathrm{kA} / \mathrm{m}$ の 時に最大となり $160 \mathrm{kA} / \mathrm{m}$ の印加磁場で零に近付くことを 確認した. 磁歪感受率では基板厚さによる大きな差は見られ なかったが, 磁場誘起運動歪感受率については基板厚さが薄 いほど大きな值を示すことを確認した。印加磁場 $20 \mathrm{ppm} /$ $\mathrm{kA} \cdot \mathrm{m}^{-1}$ において磁歪感受率はアルミニウム基板厚さ 100 $\mu \mathrm{m}$ で $25 \mathrm{ppm} / \mathrm{kA} \cdot \mathrm{m}^{-1}, 200 \mu \mathrm{m}$ で $27 \mathrm{ppm} / \mathrm{kA} \cdot \mathrm{m}^{-1}, 300$ $\mu \mathrm{m}$ で $23 \mathrm{ppm} / \mathrm{kA} \cdot \mathrm{m}^{-1}$, 磁場誘起運動丕感受率は基板厚さ $100 \mu \mathrm{m}$ で $0.39 \mathrm{ppm} / \mathrm{kA} \cdot \mathrm{m}^{-1}, 200 \mu \mathrm{m}$ で $0.22 \mathrm{ppm} / \mathrm{kA}$. $\mathrm{m}^{-1}, 300 \mu \mathrm{m}$ で $0.012 \mathrm{ppm} / \mathrm{kA} \cdot \mathrm{m}^{-1}$ を示すことを確認した. 以上の結果よりアルミニウムを基板に用いることは,
$\mathrm{Fe}_{2.4} \mathrm{Sm}$ 合金薄膜の特徵である高感受率, 高磁歪を維持した まま，大きな磁場誘起運動歪を得ることを確認した。また， 新たに磁場誘起運動歪とその感受率を用いて評価したことに より, 磁歪材料の評価だけでなく, デバイスに用いる際の設 計指標を提案した.

\section{文献}

1) H. Wakiwaka and Y. Yamada: JPN. J. Appl. Phys. 25 (2001) 1425-1433.

2) A. E. Clark and H. S. Belson: Phys. Rev. B5 (1972) 3642-3644.

3) M. Sahashi and T. Kovayashi: J Acoustical Soc. Japan 466(1990) 591-599.

4) V. Koeninger, Y. Matsumura, H. H. Uchida and H. Uchida: J. Alloy. Compd. 211/212(1994) 581-584.

5) M. Wada and H. Uchida: J. Japan. Soc. Prec. Eng. 60 (1994) 1709-1710.

6) S. H. Lim, Y. S. Choi, S. H. Han, H. J. Kim, T. Shima and H. Fujimori: J. Magn. Magn. Mater. 189(1998) 1-7.

7) J. Thornton: J. Vac. Sci. Tech. A4 (1986) 3059-3065.

8) A. Kadowaki, S. Masuda, Y. Matsumura and Y. Nishi: J. Japan Inst. Metals 69 (2005) 377-379.

9) A. Kadowaki, Y. Tsukayama, Y. Matsumura and Y. Nishi: J. Japan Inst. Metals 69(2005) 233-236.

10) A. Kadowaki, K. Takahashi, Y. Matsumura and Y. Nishi: J. Japan Inst. Metals 69(2005) 373-376.

11) S. Masuda, Y. Matsumura and Y. Nishi: J. Japan Inst. Metals 69 (2005) 747-750.

12) K. Takahashi, S. Masuda, Y. Tsukayama, Y. Matsumura and Y. Nishi: J. Japan Inst. Metals 69(2005) 671-675.

13) S. Masuda, Y. Matsumura and Y. Nishi: J. Japan Inst. Metals 70(2006) 166-168.

14) A. C. Tam and H. Schroeder: IEEE trans. magn. 25(1989) 2629-2637.

15) ICDD Card No. Al: 4-787, $\mathrm{Sm}_{2} \mathrm{O}_{3}: 74-1989$.

16) T. Suzuki and Y. Moriguchi: Titanium no ohanashi (Japanese Standards Association, 1995) pp. 61

17) M. Rosen, H. Klimker, U. Atzmony and M. P. Dariel: Phys. Rev. B 9(1974) 254-258.

18) J. J. Wortman and R. A. Evans: J. Appl. Phys. 36(1965) 153166.

19) A. E. Clark and H. Eda: Magnetostrictive Materials (The Nikkan Kogyo Shinbun, Ltd., Tokyo, 1995) pp. 67. 